УДК 541.123.2:546.681'23

ISSN 1606-867X

DOI: https://doi.org/10.17308/kcmf.2019.21/2363

Поступила в редакцию 13.11.2019

Поступила в печать: 15.12.2019

\title{
T-x-диаграмма системы Ga - Se в диапазоне составов 48.0 - 61.5 мол. \% Se по данным термического анализа
}

\author{
(2019 А. В. Косяков, И. Н. Некрылов, Н. Ю. Брежнев, С. С. Березин, Е. Н. Малыгина, \\ А. Ю. Завражнов
}

\author{
Воронежский государственный университет \\ Университетская площадь, д. 1, 394018 Воронеж, Российская Федерация
}

\begin{abstract}
Аннотация. Целью настоящей работы было термографическое исследование $T$ - $x$ диаграммы системы Ga - Se в диапазоне температур от 500 до $1100^{\circ} \mathrm{C}$ и в диапазоне составов от 48.0 до $61.5 \mathrm{~mol} \% \mathrm{Se}$. Методом исследования являлся дифференциальный термический анализ с компьютерной регистрацией данных. Получены свидетельства о наличии ретроградного солидуса фазы $\gamma$-GaSe со стороны селена (с областью гомогенности в несколько десятых mol \% при температурах выше эвтектической) и о независимом существовании близких по составу фаз $\varepsilon$-GaSe и $\gamma$-GaSe. При этом более богатая галлием фаза $\varepsilon$-GaSe испытывает перитектический распад с образованием расплава $\left(\mathrm{L}_{2}\right)$ и $\gamma$-GaSe. Для температуры предполагаемой перитектической реакции получено значение $921 \pm 2{ }^{\circ} \mathrm{C}$. Вместе с тем, на данном этапе работ не получено никаких данных в пользу существования ожидавшейся (по аналогии с системой $\mathrm{Ga}-\mathrm{S}$ ) высокотемпературной модификации, близкой по составу к сесквиселениду галлия $\left(\mathrm{Ga}_{2} \mathrm{~S}_{3}\right)$. Другие результаты, полученные в настоящей работе (характер и температуры плавления промежуточных фаз, температуры эвтектического и монотектического превращений, а также координата эвтектического состава), хорошо согласуются с литературными данными по исследованной системе.
\end{abstract}

Ключевые слова: фазовая диаграмма, дифференциальный термический анализ, система Ga-Se.

\section{ВВЕДЕНИЕ}

При исследованиях фазовых диаграмм даже достаточно простых бинарных систем до сих пор нередки случаи обнаружения новых промежуточных фаз (например $\mathrm{BiRh}_{0.81}[1]$ или $\mathrm{mp}-\mathrm{BaP}_{3}$ [2]). Сложности их обнаружения и идентификации связаны, в основном, с тем, что эти фазы существуют при относительно высоких температурах (свыше $600^{\circ} \mathrm{C}$ ) и не могут быть выделены при обычных процедурах закаливания. Это в полной мере относится и к одному из высокотемпературных сульфидов галлия, который был недавно обнаружен нами в системе $\mathrm{Ga}-\mathrm{S}$ [3-5]. Этот сульфид (получивший название $\sigma$-фазы, или $\mathrm{Ga}_{2+\delta} \mathrm{S}_{3}$ ) содержит $\sim 59 \mathrm{~mol} \%$ серы и реализуется на фазовой диаграмме только в узком диапазоне температур - от 877 до $922{ }^{\circ} \mathrm{C}$. Указанная $\sigma$-фаза имеет дефектную сфалеритоподобную кристаллическую решетку.

Завражнов Александр Юрьевич, e-mail: alzavr08@ rambler.ru
Отметим, что системе $\mathrm{Ga}-\mathrm{S}$ оказывается наиболее близка система $\mathrm{Ga}$ - $\mathrm{Se}$ - как по общему виду фазовой диаграммы (рис. 1), так и по структурам и свойствам промежуточных фаз. Так, температуры конгруэнтно плавящихся сульфидов - GaS и $\mathrm{Ga}_{2} \mathrm{~S}_{3}$ всего на 50-100 ${ }^{\circ} \mathrm{C}$ выше аналогичных температур для селенидов такой же стехиометрии [6]. Монохалькогениды галлия $\mathrm{GaS}$ и $\mathrm{GaSe}$ кристаллизуются в гексагональной слоистой структуре, основанной на чередовании связанных между собой ван-дер-Ваальсовыми силами четырехслойных пакетов $\mathrm{Ch}-\mathrm{Ga}-$ $\mathrm{Ga}-\mathrm{Ch}(\mathrm{Ch}=\mathrm{Se}, \mathrm{S})$. Сесквихалькогениды $\mathrm{Ga}_{2} \mathrm{~S}_{3}$ и $\mathrm{Ga}_{2} \mathrm{Se}_{3}$ - возможно, за исключением температур предплавления - кристаллизуются в моноклинной структуре $\left(\mathrm{Ga}_{2} \mathrm{~V}_{\mathrm{Ga}}\right) \mathrm{Se}_{3}$ с упорядоченным расположением занятых галлием и вакансионных позиций $\mathrm{V}_{\mathrm{Ga}}[6]$.

С учетом этих фактов ожидали обнаружения аналога $\sigma$-фазы - кубической модификации в системе $\mathrm{Ga}-\mathrm{Se}$ в близкой области температур 


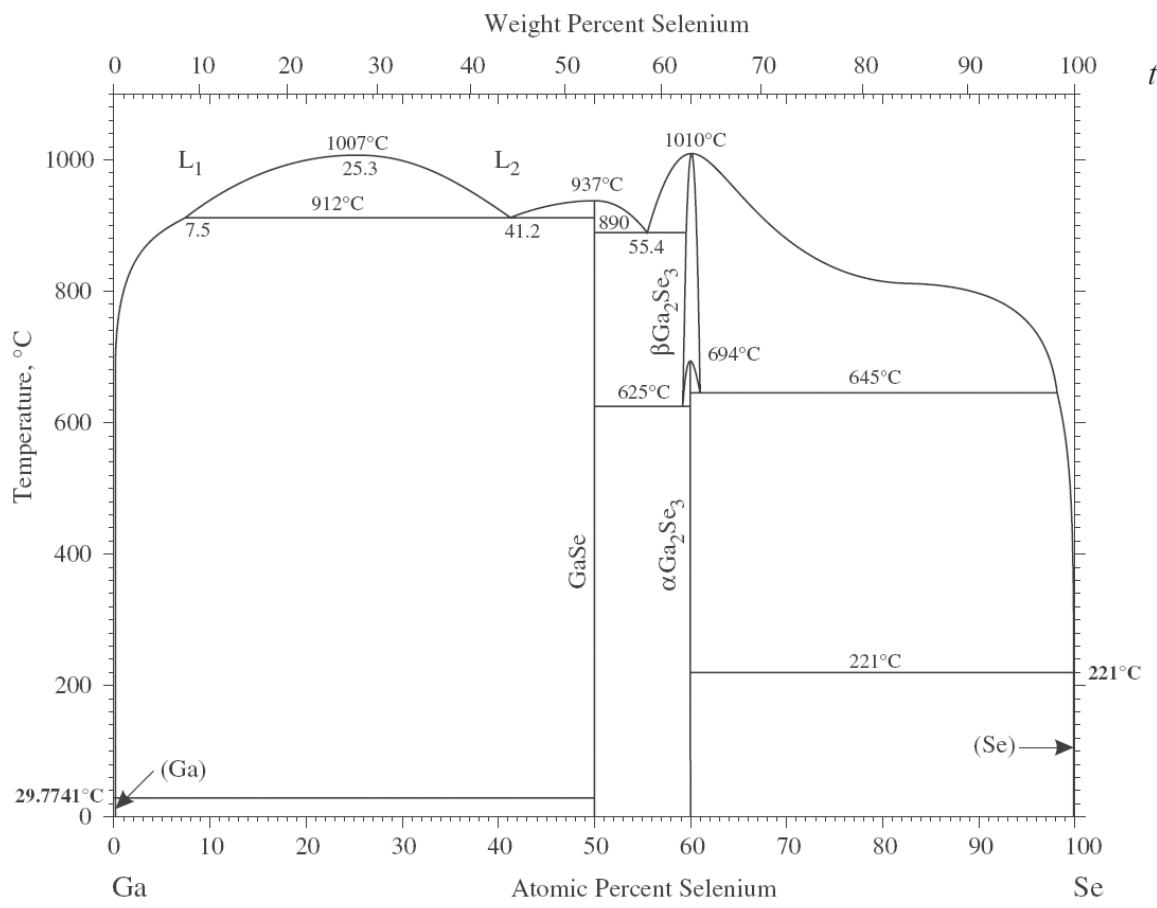

$a$

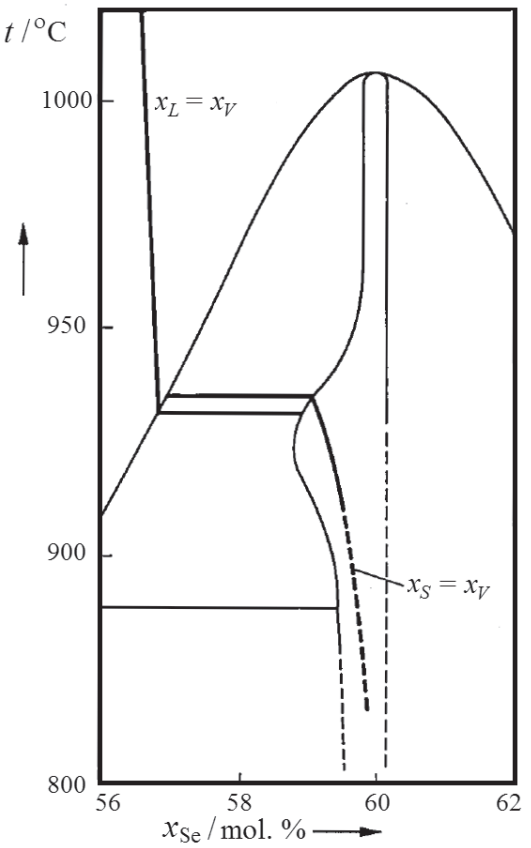

$b$

Рис. 1. a) T-x-диаграмма системы Ga - Sе согласно [6] (слева) и b) фрагмент этой диаграммы вблизи фазы $\mathrm{Ga}_{2} \mathrm{Se}_{3}$ при температурах предплавления [7] (справа)

[Fig. 1. a) $T$ - $x$-diagram of the Ga-Se system according to [6] (on the left side) and $b$ ) the fragment of this system near the region of the $\mathrm{Ga}_{2} \mathrm{Se}_{3}$-phase at the pre-melting temperatures (according to [7], see the right side)]

и составов. Более того, на образование сфалеритоподобной модификации $\left(\alpha-\mathrm{Ga}_{2} \mathrm{Se}_{3}\right)$ при дистектоидном превращении фазы с моноклинной структурой $\left(\beta-\mathrm{Ga}_{2} \mathrm{Se}_{3}\right)$ указывается в [7]. В этом же исследовании показано, что для обогащенной галлием границы области гомогенности $\alpha-\mathrm{Ga}_{2} \mathrm{Se}_{3}$ наблюдается ретроградный солидус. Эта ретроградность коррелирует с обнаруженным перегибом линии ликвидуса (рис. 1б).

Не меньший интерес представляет собой и область фазовой диаграммы с составами, близкими к 50 mol \%. Так, авторы [8] в ходе тензиметрических исследований нашли, что фаза GaSe имеет выраженный ретроградный солидус со стороны селена в узкой температурной области ( от 890 до $940{ }^{\circ} \mathrm{C}$ ). Как и для фазы $\alpha-\mathrm{Ga}_{2} \mathrm{Se}_{3}$, ретроградность солидуса моноселенида галлия коррелирует с обнаруженным в [9] перегибе линии ликвидуса. Хорошо известно, что на соответствующей ретроградному солидусу линии ликвидуса часто наблюдается перегиб при температуре, соответствующей максимальной растворимости одного из компонентов твердой фазы [10]. Наличие такого специфического поведения границ областей гомогенности сразу двух соседних фаз (обращенных ретроградными выступами друг к другу) является достаточно редким случаем.
Вместе с тем, в последних обзорных работах [6, 11] специфический характер линии ликвидуса на $T-x$-фазовой диаграмме системы $\mathrm{Ga}-\mathrm{Se}$ не прослеживается (рис. 1). Дискуссионным является и вопрос относительно фазовой принадлежности соединений с составами, близкими к GaSe. B работе [12] на основании результатов рентгеновского анализа образцов GaSe, приведенных к определенным составам в отжиговых экспериментах, утверждается, что из двух политипов $\mathrm{GaSe}-\varepsilon(2 \mathrm{H})$ и $\gamma(3 \mathrm{R})$ - при температуpax свыше $700{ }^{\circ} \mathrm{C}$ первый воспроизводимо получается в условиях избытка нестехиометрического галлия, а второй - при избытке нестехиометрического селена. Такое утверждение означает, что между обеими модификациями $\mathrm{GaSe}$ должна быть узкая гетерогенная область на фазовой диаграмме. Однако нам не удалось найти в литературе соответствующих изображений T-х-диаграммы.

С учетом изложенного целью настоящей работы являлось термографическое исследование (ДТА) $T$ - $\chi$-диаграммы системы Ga - Se в концентрационной области от 48.0 до $61.5 \mathrm{~mol} \%$, т. е. в таком диапазоне составов, который захватывает области существования наиболее интересных фаз со стехиометриями, близкими к $\mathrm{GaSe}$ и 
$\mathrm{Ga}_{2} \mathrm{Se}_{3}$. При этом основная задача состояла в выяснении вопроса о возможности регистрации твердофазных превращений $\mathrm{Ga}_{2} \mathrm{Se}_{3}$ средствами термического анализа.

\section{МЕТОДИКА ЭКСПЕРИМЕНТА}

В ходе термического анализа исследовались сплавы системы $\mathrm{Ga}$ - Se, содержащие от 48.0 до $61.5 \mathrm{~mol} \% \mathrm{Se}$ (всего - 40 образцов различных составов). Синтез этих сплавов из простых веществ (Ga-00, Se квалификации ОСЧ, дополнительно перегнанный) проводили в вакуумированных кварцевых ампулах при температуре $1100{ }^{\circ} \mathrm{C}$ в течение 3 часов при периодическом встряхивании. Далее вещества охлаждали в режиме выключенной печи. После вскрытия ампул содержимое количественно переносили в сосуды Степанова. Последние вакуумировали до остаточного давления $10^{-4} \mathrm{~Pa}$ и отпаивали.

Эксперименты с применением дифференциального термического анализа с компьютерной регистрацией данных проводили по методике, описанной в [7]. Исследуемый диапазон темпе- ратур составлял от 500 до $1100^{\circ} \mathrm{C}$. Использовали преимущественно режимы нагревания со скоростями от 0.9 до $4.2 \mathrm{~K} / \mathrm{min}$. При этом в ряде экспериментов исследуемое вещество отжигали в сосудах Степанова в течение 10 - 12 h при температурах, для которых полагали возможным образование кубической фазы (650 и $\left.700{ }^{\circ} \mathrm{C}\right)$, а затем приступали к термографированию в надежде обнаружить распад этой фазы. Для качественного подтверждения результатов экспериментов, для некоторых сплавов термический анализ вели и в режимах охлаждения (также со скоростями от 0.9 до $4.2 \mathrm{~K} / \mathrm{min})$.

\section{РЕЗУЛЬТАТЫ ЭКСПЕРИМЕНТА И ИХ ОБСУЖДЕНИЕ}

Всего было проведено 63 термографических эксперимента. Соответствующие данные представлены на рис. 2. Общий вид полученного фрагмента $T$ - $\chi$-диаграммы (рис. 2) не отличается от данных [6] (см. рис. 1). Так, плавление фаз GaSe (точнее - $\gamma$-GaSe) и $\mathrm{Ga}_{2} \mathrm{Se}_{3}$ оказывается, вне сомнения, конгруэнтным (тем-

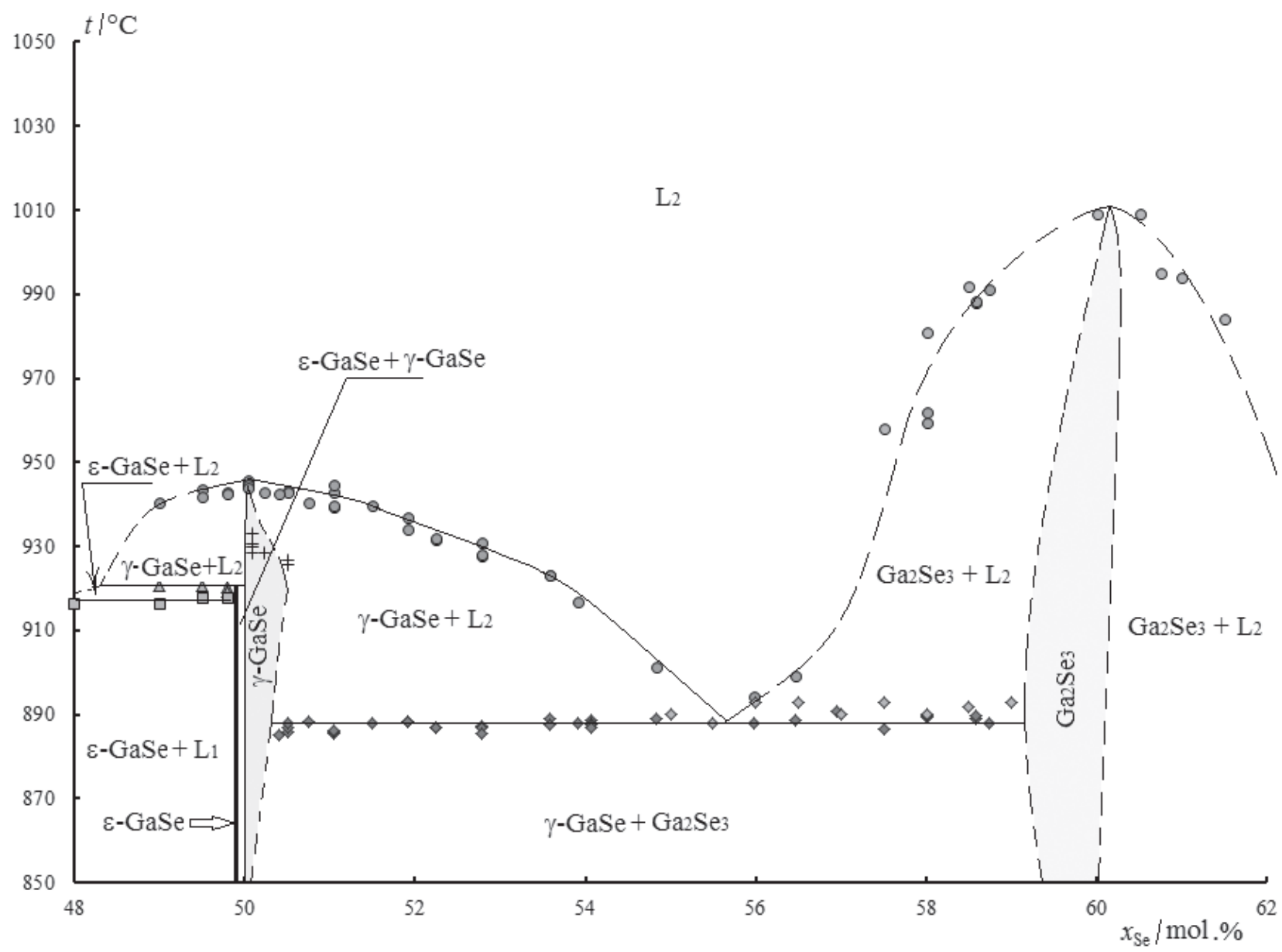

Рис. 2. Фрагмент T-х-диаграммы системы Ga -Se по данным настоящей работы [Fig. 2. The fragment of the $T$ - $x$-diagram of the $\mathrm{Ga}$ - Se system: the data of the present paper] 
пературы $944 \pm 2$ и $\left.1010 \pm 2{ }^{\circ} \mathrm{C}\right)$; между этими фазами при температуре $888 \pm 2{ }^{\circ} \mathrm{C}$ и составе $\sim 55.5 \mathrm{~mol} \%$ Se четко фиксируется эвтектическая горизонталь (1)

$$
\gamma-\mathrm{GaSe}+\mathrm{Ga}_{2} \mathrm{Se}_{3}=\mathrm{L}_{2} .
$$

Отвечающие этой горизонтали эндоэффекты проявляются на термограммах нагревания для образцов с содержанием селена от 50.1 до 59.0 мол. \%. Для монотектической горизонтали превращения (2) получена температура $916 \pm 2{ }^{\circ} \mathrm{C}$

$$
\mathrm{L}_{2}=\mathrm{L}_{2}+\varepsilon-\mathrm{GaSe},
$$

где $\mathrm{L}_{1}$ и $\mathrm{L}_{2}-$ жидкость на основе металлического галлия и расплав селенидов галлия соответственно.

Все приведенные здесь данные хорошо согласуются с результатами последних обзорных работ $[6,11]$ по рассматриваемой системе.

Вместе с тем, обращают на себя внимание определенные детали, не обсуждавшиеся в $[6,11]$.
T-х-диаграмма системы Ga-Se в диапазоне составов...

1. Термограммы сплавов с составами от 49.0, 49.5 и 49.8 мол. \% Se при всех скоростях нагревания демонстрировали по два излома в узкой области температур (рис. 3).

Если первый излом можно связать с монотектическим превращением (2) с температурой $t=916 \pm 2{ }^{\circ} \mathrm{C}$, то второй, более высокотемпературный излом $\left(t=921 \pm 2{ }^{\circ} \mathrm{C}\right)$ с учетом данных [12] может быть связан с перитектическим распадом $\varepsilon-G a S e$ :

$$
\varepsilon-\mathrm{GaSe}=\mathrm{L}_{2}+\gamma-\mathrm{Ga}_{2} \mathrm{Se}_{3},
$$

B пользу такой интерпретации свидетельствует, и отсутствие второго излома на термограммах образца содержанием селена 48.0 мол. Se.

2. Для сплавов с содержанием селена от 50.1 до 50.8 мол. \% на термограммах нагревания происходило восстановление базовой линии при температурах, превышающих эвтектическую (рис. 4). Аналогичное восстановление базовой

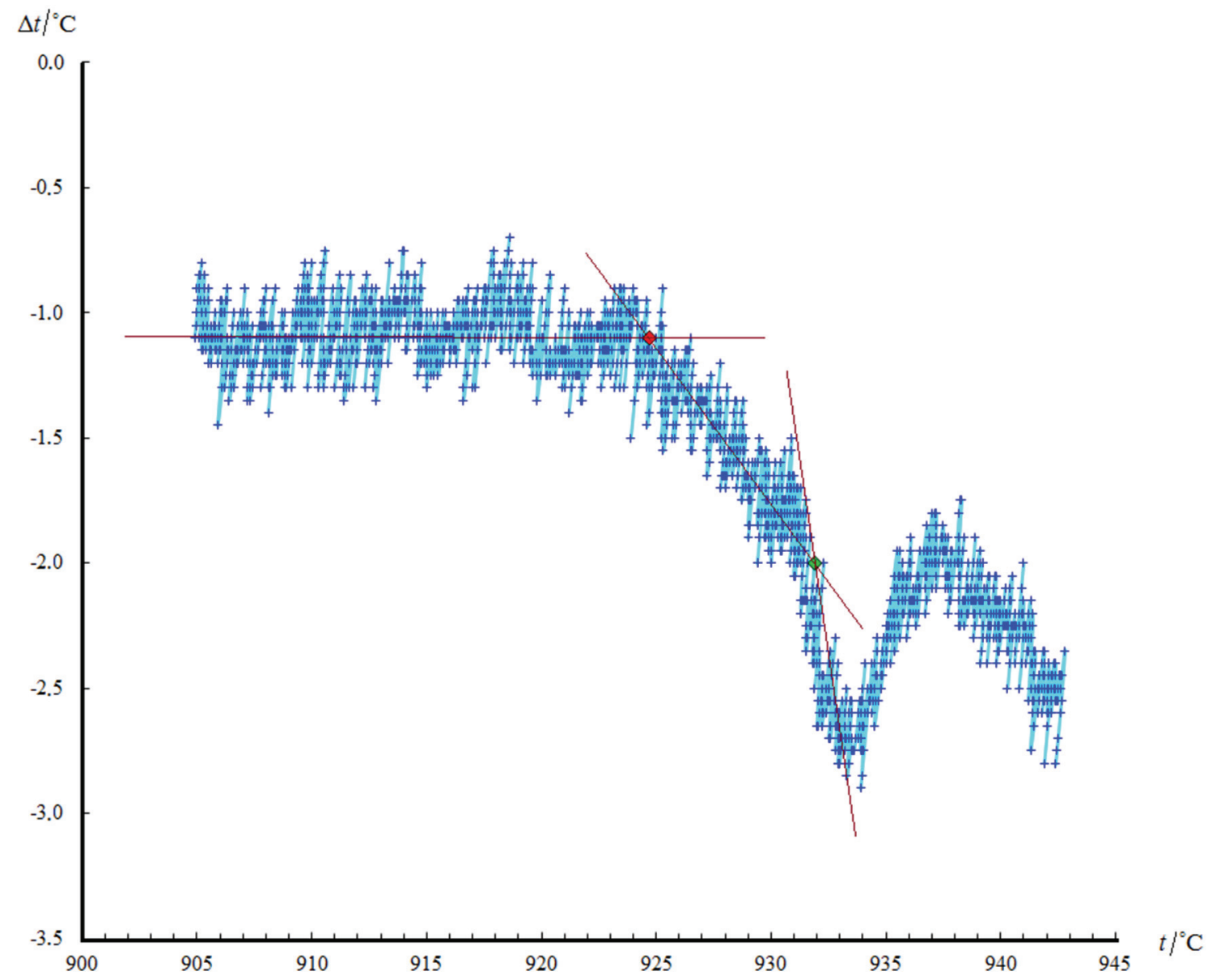

Рис. 3. Фрагмент «дифференциальной» термограммы сплава с содержанием Se $49.0 \mathrm{~mol}$ \% с двумя изломами. Скорость нагревания $1.9 \mathrm{~K} / \mathrm{min}$

[Fig. 3. Fragment of the «differential» thermal pattern for the alloy of $49.0 \mathrm{~mol} \%$ Se content: see two breakpoints. The heating rate is $1.9 \mathrm{~K} / \mathrm{min}$ ] 


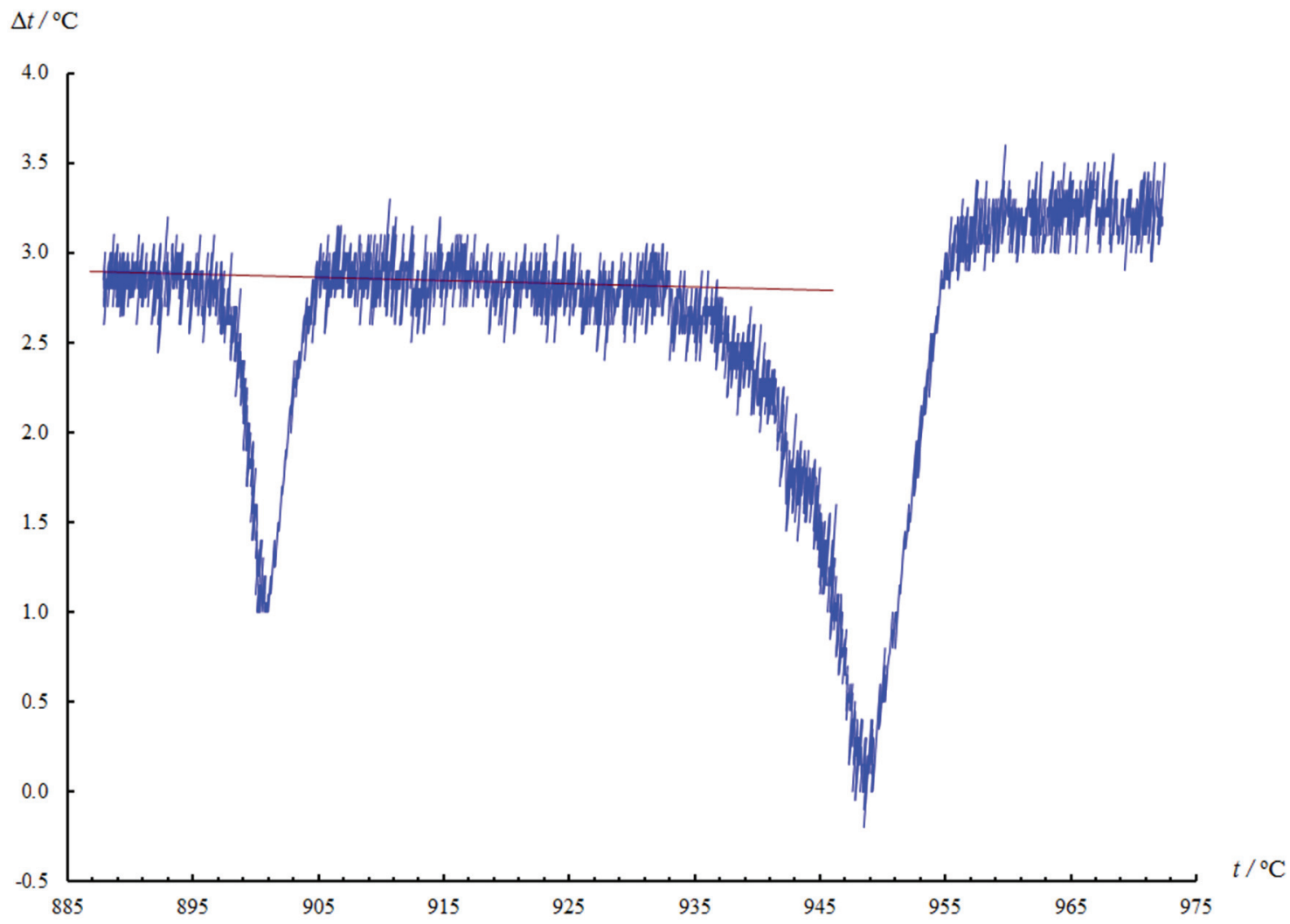

Рис. 4. «Дифференциальная» термограмма нагревания для сплава с содержанием селена $50.8 \mathrm{~mol} \%$. Базовая линия восстанавливается после эвтектического превращения и остается практически неизменной в за-эвтектической области температур от 910 до $930{ }^{\circ} \mathrm{C}$

[Fig. 4. The «differential» thermal pattern (heating) for the alloy of $50.8 \mathrm{~mol} \%$ Se content. The recovery of the baseline takes places after the eutectic transformation; this baseline remains almost unchanged at aftereutectic region from the temperature of $\sim 910$ to $930{ }^{\circ} \mathrm{C}$ ]

линии имело место и на термограммах охлаждения (температуры ниже эвтектического превращения, рис. 5).

Эти наблюдения находятся в хорошем согласовании с представлениями [8] о ретроградном солидусе $\gamma-\mathrm{GaSe}$ со стороны селена. Действительно, совпадение базовых линий на термограммах нагревания для до-эвтектических и за-эвтектических температур - но ниже полного плавления фазы - может указывать на ретроградность солидуса. Именно при таком солидусе образование расплава может прекращаться (на некотором интервале температур), даже если образец нагревается при за-эвтектических температуpax. (Заметим, что такое же прекращение плавления, сопровождающееся с восстановлением базовых линий на термограммах должно наблюдаться и при почти вертикальном наклоне линии ликвидуса; однако, рассматриваемой диаграмме эта ситуация не соответствует - рис. 2). C картиной ретроградного солидуса $\gamma$-GaSe coгласуется и тот факт, что для образцов с содержанием селена от 50.1 до $50.5 \mathrm{~mol} \%$ на термо- граммах нагревания отмечаются дополнительные эндоэффекты при температурах от 927 до $933^{\circ} \mathrm{C}$. Такие эффекты могут соответствовать повторному образованию расплава при температурах, значительно превышающих эвтектическую (переход из области гомогенности фазы в двухфазную область $\gamma$-GaSe $+\mathrm{L}_{2}$ ).

3. Не удалось зафиксировать никаких превращений, похожих на образование высокотемпературной фазы в областях концентраций от 55.5 до $60.0 \mathrm{~mol} \%$ и температур от 700 до $1015^{\circ} \mathrm{C}$. Это может означать, что данное превращение либо не является энантиотропным (и тогда не должно отображаться на фазовой диаграмме, отражающей только устойчивые фазы), либо обладает чрезвычайно малым тепловым эффектом, не достаточным для его обнаружения средствами ДТА.

\section{ЗАКЛЮЧЕНИЕ}

По результатам дифференциального термического анализа исследован участок $T$ - $x$ - диаграммы системы Ga-Se в диапазоне концентра- 


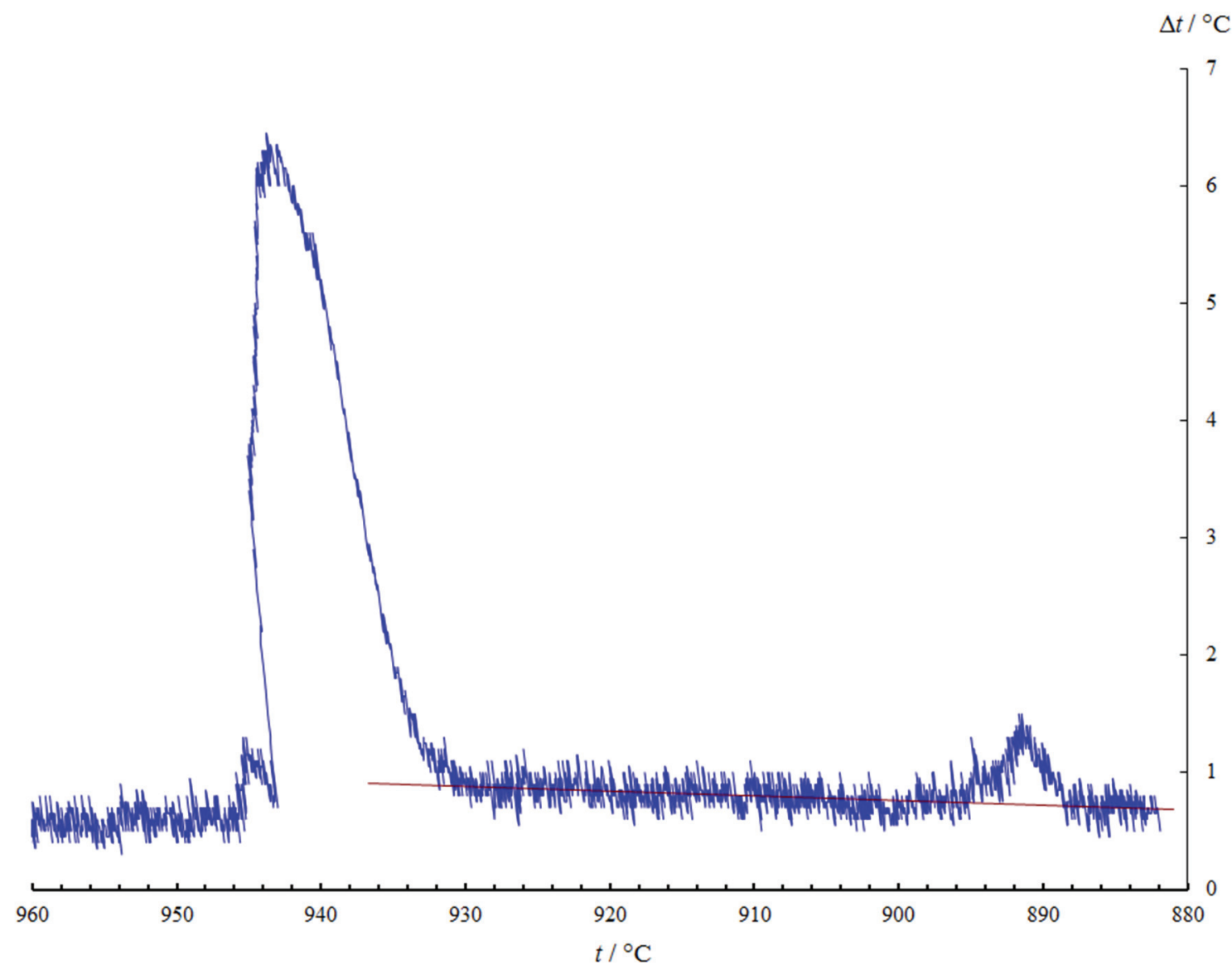

Рис. 5. «Дифференциальная» термограмма охлаждения для сплава с содержанием селена 50.8 mol \%.

Базовая линия восстанавливается после эвтектического превращения (кристаллизации)

[Fig. 5. The «differential» thermal pattern (cooling) for the alloy of $50.8 \mathrm{~mol} \%$ Se content. The recovery of the baseline takes places after the eutectic transformation (crystallization process in this case)

ций от 48.0 до $61.5 \mathrm{~mol} \% \mathrm{Se}$. Температуры конгруэнтного плавления фаз $\gamma$-GaSe и $\mathrm{Ga}_{2} \mathrm{Se}_{3}(944 \pm 2$ и $1010 \pm 2{ }^{\circ} \mathrm{C}$ соответственно), температура монотектической реакции $\mathrm{L}_{2}=\mathrm{L}_{2}+\varepsilon$-GaSe $\left(916 \pm 2{ }^{\circ} \mathrm{C}\right)$, а также координаты эвтектической точки между $\gamma$-GaSe и $\mathrm{Ga}_{2} \mathrm{Se}_{3}\left(888 \pm 2{ }^{\circ} \mathrm{C}\right.$, состав $\left.\sim 55.5 \mathrm{~mol} \% \mathrm{Se}\right)$ хорошо согласуются с литературными данными. Новизна результатов состоит в том, что получены свидетельств о наличии ретроградного солидуса фазы $\gamma$-GaSe со стороны селена (с областью гомогенности в несколько десятых мол. \% при температурах выше эвтектической) и о независимом существовании близких по составу фаз $\varepsilon^{-}$ $\mathrm{GaSe}$ и $\gamma$-GaSe. При этом более богатая галлием фаза $\varepsilon$-GaSe испытывает перитектический распад с образованием расплава $\left(\mathrm{L}_{2}\right)$ и $\gamma-\mathrm{GaSe}$. Для температуры предполагаемой перитектической реакции получено значение $921 \pm 2{ }^{\circ} \mathrm{C}$. Вместе с тем, на данном этапе работ не получено никаких данных в пользу существования ожидавшейся (по аналогии с системой $\mathrm{Ga}-\mathrm{S}$ ) высокотемпературной модификации, близкой по составу к сесквиселениду галлия $\left(\mathrm{Ga}_{2} \mathrm{~S}_{3}\right)$.

\section{ИСТОЧНИК ФИНАНСИРОВАНИЯ}

Работа выполнена при поддержке гранта РФФИ 18-33-00900 мол_а.

\section{КОНФЛИКТ ИНТЕРЕСОВ}

Авторы декларируют отсутствие явных и потенциальных конфликтов интересов, связанных с публикацией настоящей статьи.

\section{СПИСОК ЛИТЕРАТУРЫ}

1. Kainzbauer P., Richter K. W., Ipser H. The binary Bi-Rh phase diagram: stable and metastable phases // J. Phase Equilibria and Diffusion, 2018, v. 39(1), pp. 1734. DOI: https://doi.org/10.1007/s11669-017-0600-5

2. Dolyniuk J.-A., Kaseman D. C., Sen S., Zhao J., Osterloh F. E., Kovnir K. mP-BaP3: A new phase from an old binary system // Chem. Eur. J., 2014, v. 20, pp. 10829-10837, DOI: https://doi.org/10.1002/ chem.201305078

3. Березин С. С., Завражнов А. Ю., Наумов А. В., Некрылов И. Н., Брежнев Н. Ю. Фазовая диаграмма системы Ga-S в области 48.0-60.7 мол. \% S // Конденсированные среды и межфазные границы, 2017, 
т. 19(3), c. 321-335. DOI: https://doi.org/10.17308/ kcmf.2017.19/208

4. Волков В. В., Сидей В. И., Наумов А. В., Некрылов И. Н., Брежнев Н. Ю., Малыгина Е. Н., Завражнов А. Ю. Высокотемпературная кубическая модификация сульфида галлия (Xs = 59 мол. \%) и $T, x$-диаграмма системы Ga - S // Конденсированные среды и межфазные границы, 2019, т. 21(1), с. 37-50. DOI: https://doi.org/10.17308/kcmf.2019.21/715

5. Zavrazhnov A., Berezin S., Kosyakov A., Naumov A., Berezina M., Brezhnev N. J. The phase diagram of the $\mathrm{Ga}-\mathrm{S}$ system in the concentration range of 48.0-60.7 mol \% S // Thermal Analysis and Calorimetry, 2018, v. 134(1), pp. 483-492. DOI: https://doi. org/10.1007/s10973-018-7124-z

6. Okamoto H. Ga-Se (Gallium-Selenium) // J. Phase Equilibria and Diffusion, 2009, v. 30, p. 658. DOI: https://doi.org/10.1007/s11669-009-9601-3

7. Dieleman J., Sanders F. H. M. Phase diagram of the Ga-Se system // Phillips J. Res., 1982, v. 37(4), pp. $204-229$.

8. Zavrazhnov A. Yu. Turchen D. N., Goncharov Eu. G., Zlomanov V. P. Manometric method for the study of $P-T-x$ diagrams // J. Phase Equilibria and Diffusion, 2001, v. 22(4), pp.482-490. DOI: https://doi. org/10.1361/105497101770333063

9. Shtanov V. I, Komov A. A, Tamm M. E., Atrashenko D. V., Zlomanov V.P. Gallium-selenium system phase diagram and photoluminescence spectra of GaSe crystals // Doklady Akademii nauk SSSR, 1998, v. 361(3), pp. 357-361. (in Russ.)

10. Glazov V. M., Pavlova L. M. Semiconductor and metal binary systems. Phase equilibria and chemical thermodynamics. Springer, 1989, 327 p. DOI: https:// doi.org/10.1007/978-1-4684-1680-0

11. Ider M. Pankajavalli R., Zhuang W. Thermochemistry of the Ga-Se System. J. Solid State Science and Techn., 2015, v. 4(5), Q51-Q60 DOI: https://doi. org/10.1149/2.0011507jss

12. Zavrazhnov A., Naumov A., Sidey V., Pervov V. Composition control of low-volatile solids through chemical vapor transport reactions. III. The example of gallium monoselenide: Control of the polytypic structure, non-stoichiometry and properties // Thermochimica Acta, 2012, v. 527, pp. 118-124. DOI: https://doi.org/10.1016/j.tca.2011.10.012

\title{
The $T$ - $x$ Diagram of the Ga - Se System in the Composition Range from 48.0 to $61.5 \mathrm{~mol} \%$ Se According to Thermal Analysis Data
}

\author{
(c2019 A. V. Kosyakov, I. N. Nekrylov, N. Yu. Brezhnev, S. S. Beresin, E. N. Malygina, \\ A. Yu. Zavrazhnov \\ Voronezh State University \\ 1, Universitetskaya pl., 394018 Voronezh, Russian Federation
}

\begin{abstract}
Purpose. In this study we discuss the $\mathrm{Ga}-\mathrm{Se}$ and $\mathrm{Ga}-\mathrm{S}$ systems, which have very similar shaped phase diagrams, as well as the structures and properties of their binary phases. With this consideration in mind, we anticipated discovering the selenium analogue of the sulphide cubic high-temperature phase $\mathrm{Ga}_{2+\delta} \mathrm{S}_{3}$. This recently detected phase (the so-called $\sigma$-phase) exists in the $\mathrm{Ga}-\mathrm{S}$ system in a narrow range of temperatures $\left(\sim 878-922^{\circ} \mathrm{C}\right)$ and compositions (approximately $59 \mathrm{~mol} \%$ S). Additionally, we found it necessary to check the other phase relationships in the Ga - Se system. The goal of this work was to conduct a thermographic study (DTA) of the Ga - Se T-x diagram in the concentration range from 48.0 to $61.5 \mathrm{~mol} \%$ Se and temperature range from 500 to $1100{ }^{\circ} \mathrm{C}$ and to find out whether there is a selenium analogue of the sulphide $\sigma$-phase."

Methods and methodology. 40 alloys of the $\mathrm{Ga}$ - Se system with various compositions were investigated. All the alloys were prepared by the fusion of weights of the metallic gallium and selenium in vacuumed and sealed quartz ampoules for 3 hours at $1100{ }^{\circ} \mathrm{C}$. The ingots, weighing from 1 to $4 \mathrm{~kg}$, were quantitatively transferred to Stepanov's vessels, then vacuumed and sealed. Thermographs were obtained for the temperature range from 0.9 to $4.2 \mathrm{~K} / \mathrm{min}$ with a temperature variation rate from $500{ }^{\circ} \mathrm{C}$ to $1100^{\circ} \mathrm{C}$.

Results. Based on the results of the differential thermal analysis, the T-x diagram of the $\mathrm{Ga}-\mathrm{Se}$ system was studied in the concentration range from 48.0 to $61.5 \mathrm{~mol} \%$ Se. The congruent melt-
\end{abstract}

Zavrazhnov Alexander Yurievich, e-mail: alzavr08@rambler.ru 
ing temperatures of the $\gamma$-GaSe and $\mathrm{Ga}_{2} \mathrm{Se}_{3}$ phases ( $944 \pm 2$ and $1010 \pm 2{ }^{\circ} \mathrm{C}$ correspondingly), the temperature of the monotectic reaction $\mathrm{L}_{2}=\mathrm{L}_{2}+\varepsilon-\mathrm{GaSe}\left(916 \pm 2{ }^{\circ} \mathrm{C}\right)$, as well as the coordinates of the eutectic point between $\gamma$-GaSe and $\mathrm{Ga}_{2} \mathrm{Se}_{3}\left(888 \pm 2{ }^{\circ} \mathrm{C}\right.$, composition $\sim 55.5 \mathrm{~mol} \% \mathrm{Se}$ ), correlate well with the reported data. The novelty of the results is that we obtained evidence of the retrograde solidus of the $\gamma$-GaSe phase on the part of selenium (with a homogeneity region of several tenths of mol \% at temperatures above the eutectic) and evidence of the independent existence of the compositionally similar $\varepsilon$-GaSe and $\gamma$-GaSe phases. In this case, the richer gallium-enriched phase $\varepsilon$-GaSe peritectically melts with the formation of a liquid (L2) and solid $\gamma$-GaSe $\left(921 \pm 2{ }^{\circ} \mathrm{C}\right)$. However, at this stage no evidence in favour of the existence of the hightemperature modification type such as $\mathrm{Ga}_{2+\delta} \mathrm{Se}_{3}$ was obtained.

Keywords: phase diagram, differential thermal analysis, Ga-Se system.

\section{SOURCE OF FINANCING}

The reported study was supported by a grant from the Russian Foundation for Basic Research (project No.18-33-00900-360595 mol_a).

\section{CONFLICT OF INTEREST}

The authors declare the absence of obvious and potential conflicts of interest related to the publication of this article.

\section{REFERENCES}

1. Kainzbauer P., Richter K. W., Ipser H. The binary $\mathrm{Bi}-\mathrm{Rh}$ phase diagram: stable and metastable phases. J. Phase Equilibria and Diffusion, 2018, v. 39(1), pp. 17-34. DOI: https://doi.org/10.1007/s11669-0170600-5

2. Dolyniuk J.-A., Kaseman D. C., Sen S., Zhao J., Osterloh F. E., Kovnir K. mP-BaP3: A new phase from an old binary system. Chem. Eur. J., 2014, v. 20, pp. 10829-10837, DOI: https://doi.org/10.1002/ chem.201305078

3. Berezin S. S., Zavrazhnov A. Yu., Naumov A. V., Nekrylov I. N., Brezhnev N. Yu. The phase diagram of the $\mathrm{Ga}-\mathrm{S}$ system in the concentration range 48.0 to $60.7 \mathrm{~mol} \% \mathrm{~S}$. Kondensirovannye sredy i mezhfaznye granitsy [Condensed Matter and Interphases], 2017, v. 19(3), pp. 321-335. DOI: https://doi.org/10.17308/ kcmf.2017.19/208 (in Russ., abstract in Eng.)

4. Volkov V. V., Sidey V. I., Naumov A. V., Nekrylov I. N., Brezhnev N. Yu., Malygina E. N., Zavrazhnov A. Yu. The cubic high-temperture modification of gallium sulphide (Xs $=59 \mathrm{~mol} \%$ ) and the $T, x$-diagram of the Ga-S system. Kondensirovannye sredy i mezhfaznye granitsy [Condensed Matter and Interphases], 2019,v.21(1),pp.37-50.DOI: https://doi.org/10.17308/ kcmf.2019.21/715 (in Russ., abstract in Eng.)
5. Zavrazhnov A., Berezin S., Kosyakov A., Naumov A., Berezina M., Brezhnev N. J. The phase diagram of the $\mathrm{Ga}-\mathrm{S}$ system in the concentration range of 48.0-60.7 mol\% S. Thermal Analysis and Calorimetry, 2018, v. 134(1), pp. 483-492. DOI: https://doi. org/10.1007/s10973-018-7124-z

6. Okamoto H. Ga-Se (Gallium-Selenium). J. Phase Equilibria and Diffusion, 2009, v. 30, p. 658. DOI: https://doi.org/10.1007/s11669-009-9601-3

7. Dieleman J., Sanders F. H. M. Phase diagram of the Ga-Se Ssystem. Phillips J. Res., 1982, v. 37(4), pp. $204-229$.

8. Zavrazhnov A. Yu. Turchen D. N., Goncharov Eu. G., Zlomanov V. P. Manometric method for the study of $P$-T- $x$ diagrams. J. Phase Equilibria and Diffusion, 2001,v. 22(4), pp. 482-490. DOI: https://doi.org/ 10.1361/105497101770333063

9. Shtanov V. I, Komov A. A, Tamm M. E., Atrashenko D. V., Zlomanov V. P. Gallium-selenium system phase diagram and photoluminescence spectra of GaSe crystals. Doklady Akademii nauk SSSR, 1998, v. 361(3), pp. 357-361. (in Russ.)

10. Glazov V. M., Pavlova L. M. Semiconductor and metal binary systems. Phase equilibria and chemical thermodynamics. Springer, 1989, 327 p. DOI: https:// doi.org/10.1007/978-1-4684-1680-0

11. Ider M. Pankajavalli R., Zhuang W. Thermochemistry of the Ga-Se System. J. Solid State Science and Techn., 2015, v. 4(5), Q51-Q60 DOI: https://doi. org/10.1149/2.0011507jss

12. Zavrazhnov A., Naumov A., Sidey V., Pervov V. Composition control of low-volatile solids through chemical vapor transport reactions. III. The example of gallium monoselenide: Control of the polytypic structure, non-stoichiometry and properties. Thermochimica Acta, 2012, v. 527, pp. 118-124. DOI: https:// doi.org/10.1016/j.tca.2011.10.012
Косяков Андрей Викторович - к. х. н., доцент кафедры общей и неорганической химии, Воронежский государственный университет, Воронеж, Российская Федерация; e-mail: lavchukb@ mail.ru. ORCID iD: 0000-0001-9662-7091.
Andrew V. Kosyakov - Cand. Sci. (Chem.), Assistant Professor, Department of General and Inorganic Chemistry, Voronezh State University, Voronezh, Russian Federation; e-mail: lavchukb@ mail.ru. ORCID iD: 0000-0001-9662-7091. 
Некрылов Иван Николаевич - аспирант, кафедра общей и неорганической химии, Воронежский государственный университет, Воронеж, Российская Федерация; e-mail: icq492164858@gmail. com. ORCID iD: 0000-0003-4491-4739.

Брежнев Николай Юрьевич - аспирант, кафедра общей и неорганической химии, Воронежский государственный университет, Воронеж, Российская Федерация; ORCID iD: 0000-00023287-8614.

Малыгина Екатерина Николаевна - студентка V курса химического факультета, Воронежский государственный университет, Воронеж, Российская Федерация; e-mail: ekaterina. malygina2013@yandex.ru. ORCID iD: 0000-00017179-335X.

Завражнов Александр Юрьевич - д. х. н., профессор кафедры общей и неорганической химии, Воронежский государственный университет, Воронеж, Российская Федерация; e-mail: alzavr08@ rambler.ru. ORCID iD: 0000-0003-0241-834X.
Ivan N.Nekrylov-graduate student, Department of General and Inorganic Chemistry, Voronezh State University, Voronezh, Russian Federation; e-mail: icq492164858@gmail.com. ORCID iD: 0000-00034491-4739.

Nikolai Yu. Brezhnev - graduate student, Department of General and Inorganic Chemistry, Voronezh State University, Voronezh, Russian Federation; ORCID iD: 0000-0002-3287-8614.

Ekaterina N. Malygina - 5rd year student at Faculty of Chemistry, Voronezh State University, Voronezh, Russian Federation; e-mail: ekaterina. malygina2013@yandex.ru. ORCID iD: 0000-00017179-335X.

Alexander Yu. Zavrazhnov - Dr. Sci. (Chem.), Professor, Department of General and Inorganic Chemistry, Voronezh State University, Voronezh, Russian Federation; e-mail: al-zavr08@rambler.ru. ORCID iD: 0000-0003-0241-834X. 